\author{
Samuel SIVÁK ${ }^{1}, \quad$ Silvia MALÁKOVÁ ${ }^{2}$ Matúš LAVČÁK $^{3}$, \\ Michal PUŠKÁR ${ }^{4}$, Peter KAŠŠAY ${ }^{5}$ \\ Opiekun naukowy: Silvia MALÁKOVÁ2 \\ DOI: https://doi.org/10.53052/9788366249837.21

\section{OPRACOWANIE GEOMETRYCZNEGO MODELU KOLA ZĘBATEGO DO OCENY SZTYWNOŚCI ZAZĘBIENIA Z ZASTOSOWANIEM ANALIZY MES}

\begin{abstract}
Streszczenie: Hałas emitowany przez przekładnie jest jednym z ich negatywnych parametrów/charakterystyk. Najważniejszym czynnikiem wpływającym na emitowany hałas jest błąd przełożenia, który ma związek z ogólną sztywnością zazębienia. Sztywność zazębienia nie może być precyzyjnie zaprojektowana, ale można ją analizować - na przykład: stosując metodę elementów skończonych. Stosując system/pakiet MES, aby określić precyzyjnie rzeczywiste wartości sztywności oraz naprężeń, jest bardzo ważnym aby opierać się na jak najbardziej poprawnym modelu 3D - jak to tylko jest możliwe. Stosowano wiele metod modelowania kół zębatych, jednakże tylko nieliczne z nich pozwalają na utworzenie modelu o wysokiej dokładności. Jedną z metod modelowania jest modelowanie parametryczne, które nie tylko pozwala na stworzenie poprawnego zarysu ewolwentowego powierzchni zębów zazębionych kół, ale także umożliwia parametryzację całego modelu przekładni. Oznacza to, w konsekwencji, że można go zmieniać w zależności od zaledwie kilku parametrów. Inną metodą używaną do stworzenia modelu koła zębatego jest wygenerowanie go na podstawie chmury punktów. Użyta chmura punktów umożliwia wygenerowanie modelu zazębienia jako zakrzywionych powierzchni.
\end{abstract}

Słowa kluczowe: sztywność, modelowanie, MES

\footnotetext{
${ }^{1}$ Ing.,Technical University of Košice, Faculty of Mechanical Engineering, Department of Construction and Transport Engineering, Letná 9, 04200 Košice, e-mail: samuel.sivak@tuke.sk

2 doc. Ing. PhD.,Technical University of Košice, Faculty of Mechanical Engineering, Department of Construction and Transport Engineering, Letná 9, 04200 Košice, e-mail: silvia.malakova@tuke.sk

${ }^{3}$ Ing., Technical University of Košice, Faculty of Mechanical Engineering, Department of Construction and Transport Engineering, Letná 9, 04200 Košice, e-mail: matus.lavcak@tuke.sk

4 doc. Ing. PhD.,Technical University of Košice, Faculty of Mechanical Engineering, Department of Construction and Transport Engineering, Letná 9, 04200 Košice, e-mail: michal.puskar@tuke.sk

5 doc. Ing. PhD.,Technical University of Košice, Faculty of Mechanical Engineering, Department of Construction and Transport Engineering, Letná 9, 04200 Košice, e-mail: peter.kassay@tuke.sk
} 


\section{CREATION OF SPUR GEAR GEOMETRIC MODEL FOR EVALUATION OF MESHING STIFFNESS USING FEM ANALYSIS}

Summary: Noise is one of the negative parameters produced by the gearboxes. The biggest noise emitting factor is transmission error, which is related to the overall stiffness of the gearing. Stiffness of the gearing cannot be designed, only analyzed for example by the finite element method. For the FEM to give accurate stiffness values or stress values, it is important to base the analysis on the as accurate 3D model as possible. A lot of methods are used for the gearwheel model, but only a few create a model with high accuracy. One of these methods is parametric modeling, which cannot only give the correct involute end transmission curves, but also the full gear model can be parametrized, which in return means that it can be changed with only a few parameters. Another method uses the creation of the gear wheels from the point clouds, where this point clouds are used for the creation of the gearing via curved surfaces.

Keywords: stiffness, modeling, FEM

\section{Introduction}

A technical gearbox is a system, which is acoustically closed and therefore the noise is mostly transmitted via the vibrations of the gearbox frame and by the connected aggregates including a base frame. Dominant part of the gearbox noise level is almost always done by excitation of vibrations during the meshing of the gear wheels.

A lot of factors influence the vibrations during the meshing of the gear wheels such as, vibrations to transmitted to the gearing from the driving or driven aggregate, oscillation of shafts and bearings. All of the forementioned factors are participating on the increase of the amplitude in gearing [1]. The specific source of the noise has origin in shocks, which are made by the axial and lateral (gearing) clearance of the helical gears. This can be found in less loaded gear wheels, or on the other hand in a heavily loaded gear wheels rolling under the slow rpm. The uneven operation of the driving aggregate is contributing to the vibrations and the torsional vibration are created as well [2].

The most important cause of the noise is transmission error, which is related to the kinematic accuracy and a stiffness of the gearing. From the physical perspective the cause of the vibrations is dynamic force, which can change its amplitude, direction, or origin. For the involute gearing the most important factor is the change in amplitude, which main cause is a variable stiffness of the gearing and shocks in gear meshing caused by the deformations and the gear profiles from the theoretical ones. The gear wheels are rolled relative to each other and the contact is accompanied by elastic deformations. This result in significant deviations from the theoretical profile of the tooth, which results in a transmission error and its subsequent excess of oscillation. [3-5]

\section{Mesh stiffness}

Load in the meshed gearing influences the teeth in a way that they are deformed. Such deformation can cause some negative but also positive consequences. For the correct interpretation, it's important to have the knowledge of the deformation properties of 
gearing [6]. For the quantification of the gearing, the stiffness is generally used, which is defined as the ratio of load (length or width) to deformation.

Resulting stiffness alongside the line of action as well as the corresponding deformation for the spur gearing is shown in a Fig.1. It is obvious that the resulted stiffness $c$ has tendency to change periodically during meshing, alongside the line of action for the spur gears, where the period is equal to pitch. For approximate calculations the average value of the resulted stiffness $c_{\gamma}$ for the duration of the whole meshing is used.

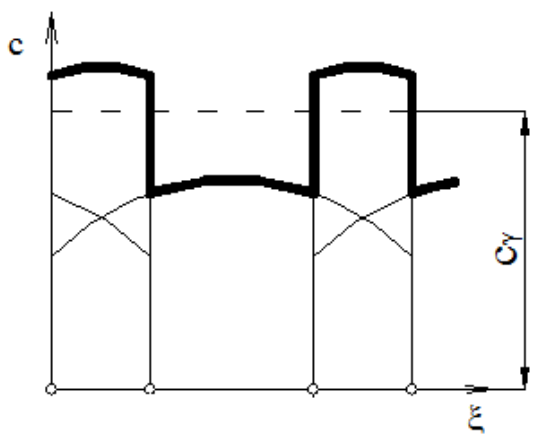

Figure 1. The course of the meshing stiffness of spur gears

Shape of the teeth on the gearing is complex, which makes the theoretical determination of deformation very difficult. Therefore, the question of the exact determination of the deformation for the gearing is still unresolved. For the practical application the experimental values or the values obtained by finite element method are used (Fig.2).

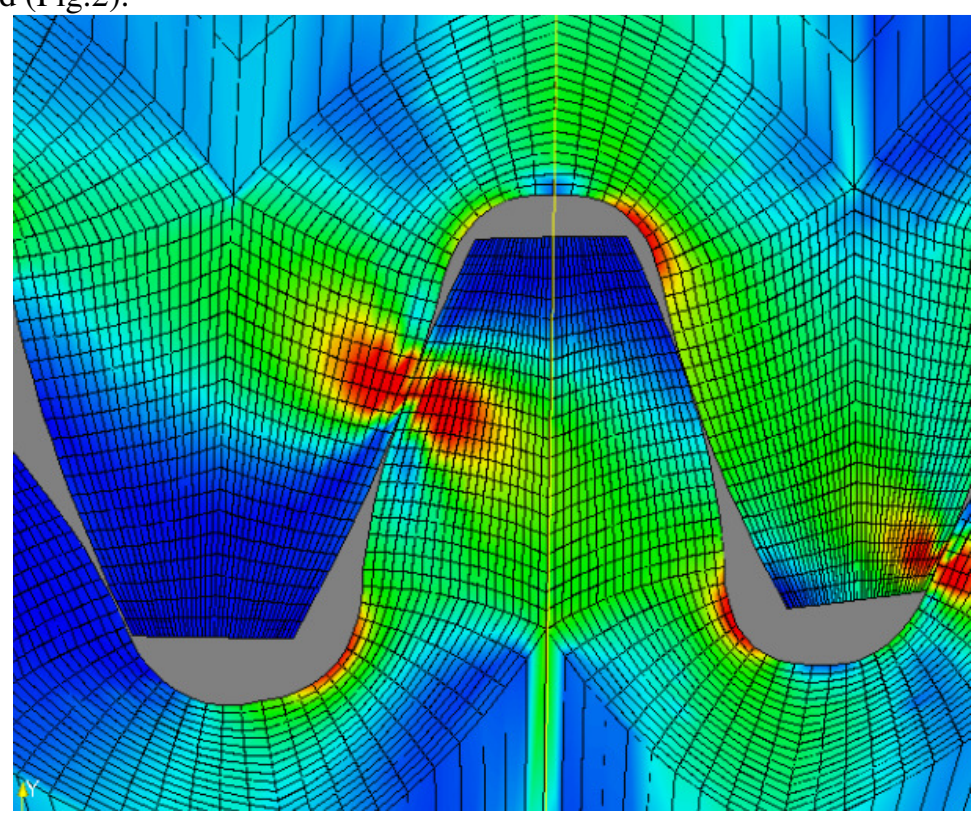

Figure 2. FEM analysis of the spur gear meshing 
Values obtained by this method are then used as a base for the determination of the gearing meshing stiffness.

\section{Creation of gear models}

Creation of the gear model can be done by a few methods. The methods differ in time it takes to create the gearwheel or the part of the gearing, and also in the final shape of the teeth. For the values obtained from the finite element method to be accurate, it is necessary to create a fine mesh. Fine mesh is composed of small elements located in a tooth, which gives better results. With this in mind it is required to create a model in the least amount of time and also with the as accurate shape as possible. Some of the older methods used to create gear wheels composed of the simulation of the machining process. Such creation was carried out as a substitution of the volumes from the solid cylinder body. The gearing creation took a lot of time, and the shape of the teeth was quite inaccurate as shown in Fig.3. Modern methods are mostly composed of parametric modeling or the modeling where the faces of the gearing are made from the point clouds imported to the 3D programs [7].

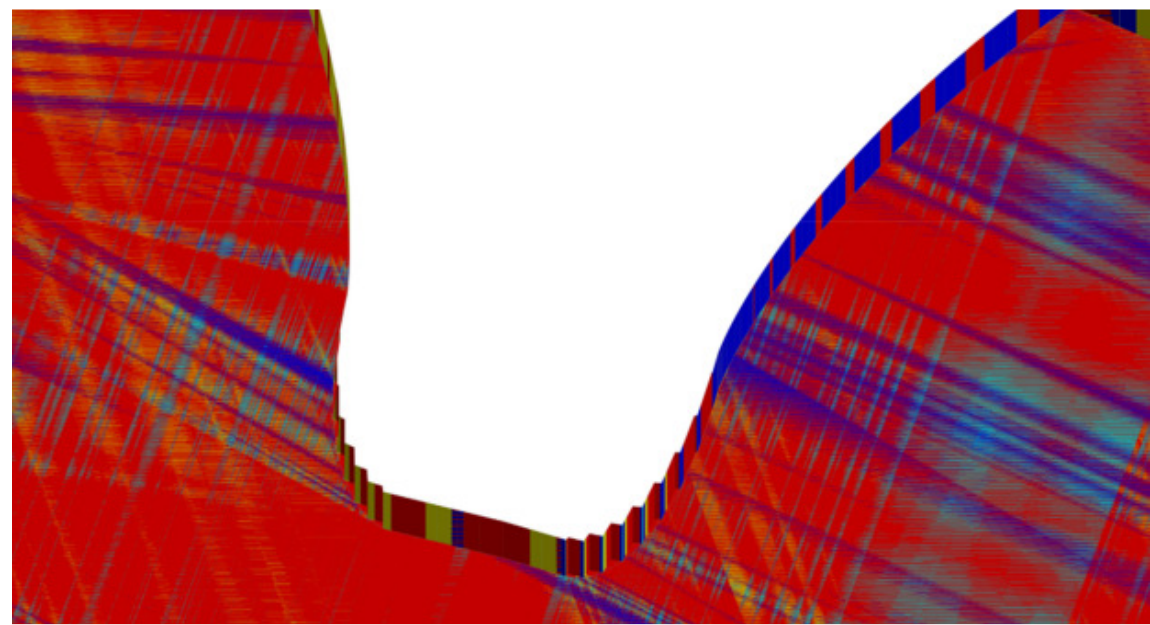

Figure 3. Choppy surface of gearing

\subsection{Parametric modeling}

Parametric modeling is one of the options to create an accurate gear model with the possibility to change whole gear wheel parameters with the retained accuracy of the shape. This type of modeling is also applicable to vide variety of gear models such as helical gears, spur gears, bevel gears or gears with special type of teeth shape. Accuracy is in the creation of the involute and in some cases in the transmission curve. Parametrically driven curves are created from the point cloud which is then connected with curves tangent to each other in every point located in point cloud. This involute is then transformed into the surface which will become the surface of the tooth.

The same approach is carried out for the transmission curve, where there are two possibilities, either the transmission curve is created as a fillet, or it has trochoidal characteristics. The transmission curve is as important as the involute for the tendency 
to concentrate stress. The transmission curve is given by the machining process in which the gear wheel is made. Final advantage of the parametric modeling is that every parameter can be bound to the next one, which gives the possibility to change the whole model just with a few values (Fig.4), [8,9]
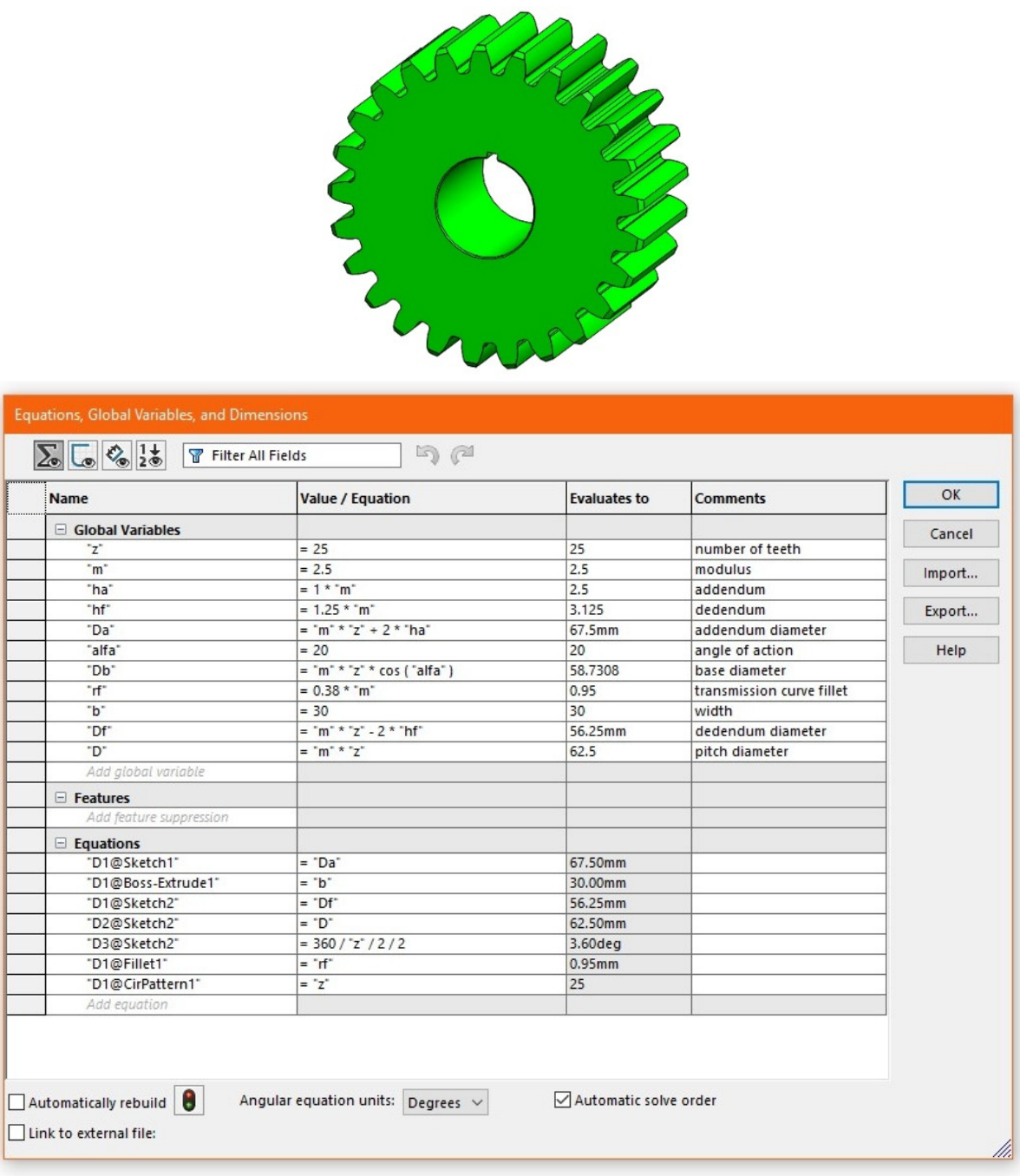

Figure 4. Parametrically driven $3 D$ model

\subsection{Modeling using point clouds}

For the models where even, the parametric modeling would take a lot of effort and time, such as the geometry of the face gears, it is possible to create the model from the point cloud which then connects and creates a surface. The face gear geometry is good example of such modeling because the tooth can be divided into two parts, working surface and transmission surface. 
The point cloud is obtained from the utilized discrete point method. This discrete point method is used with additional computational software such as MATLAB for the generation of the point cloud, which is almost impossible to create without it in a reasonable time. This method can also be used for any type of the gear wheel. Generation of the point cloud should be done in steps such as for the face gears the working surface and the transmission surface should be generated separately, then merged. This merged point cloud is then transferred to the CAD software and the surface of the tooth is created as a curved surface (Fig.5). [10]

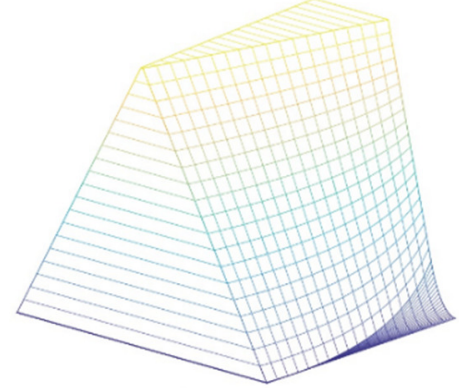

a)

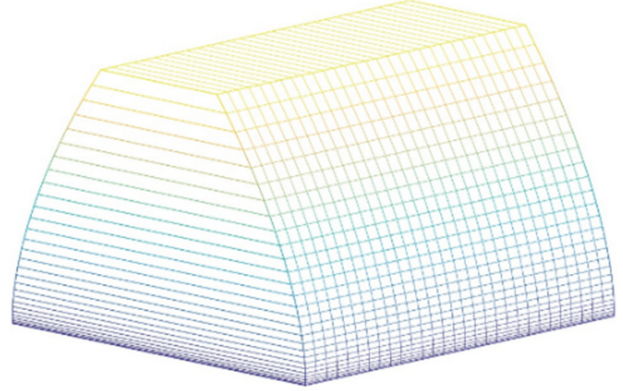

b)

Figure 5. Tooth profile of a) face gear, $b$ ) pinion

\section{Conclusion}

Increase in the mechanical power and better load characteristics for the machining machines, automobiles or in any other area is also increasing and technical level required for the operation. This results in a higher noise emissions produced, which is a negative factor for the operators and environment.

The noise is tied to the stiffness of the gearing, which gives the designers an option to check the final design using finite element method. This method outputs the values for the stiffness, stresses and the other parameters as well. For the theoretical values it is essential to base them on as accurate model as possible, so they are closer to the experimental ones.

Two methods for creation of model were proposed with respective advantages and disadvantages. The parametric modeling is the fastest and easiest one for design, yet some types of gear wheels may be very difficult to be modeled by this method. For the difficult shapes of the gear wheels there is also a method, which is based on the point cloud calculation. This point cloud is then imported to do CAD program and the tooth is created via the curved surfaces. 


\section{Acknowledgments}

This paper was developed within the projects implementation KEGA 029TUKE4/2021 "Implementation of modern educational approaches in the design of transmission mechanisms, VEGA 1/0528/20 "Solution of new elements for mechanical system tuning” and VEGA 1/0290/18 „Development of new methods of determination of strain and stress fields in mechanical system elements by optical methods of experimental mechanics".

\section{REFERENCES}

1. CHEN Z., SHAO Y.: Mesh stiffness of an internal spur gear pair with ring gear rim deformation. Mechanism and Machine Theory. 69, (2013),pp. 1-12.

2. SAPIETOVÁ A et al.: Application of optimization algorithms for robot systems designing. International Journal of Advanced Robotic Systems, 15 (1), (2018), p. $1-10$.

3. XU S., HOUSER D.: Characteristics of trochoids and their application to determining gear teeth fillet shapes. In: Mechanism and machine theory. Pergamon. $14 \mathrm{p}$.

4. PASTOR R et al.: Optimizing a quadruped robot a comparison of two methods, MM Science Journa, 2, (2021), p. 4348-4355.

5. KULKA J., MANTIČ M., FEDORKO G., MOLNÁR V.: Failure analysis concerning causes of wear for bridge crane rails and wheels, Engineering Failure Analysis. 110 (2020), p. 1-14

6. TOLVALY-ROSCA F., FORGÓ Z., MÁTÉ M.: Evaluation of a Mixed CAD Gear Modeling From Time and Precision Point of View. 8th Intemational Conference Interdisciplinarity in Engineering, INTER-ENG 2014, 9-10 October.

7. ŽUL'OVÁ L., GREGA R., KRAJŇÁK J., FEDORKO G., MOLNÁR V.: Optimization of noisiness of mechanical system by using a pneumatic tuner during a failure of piston machine, Engineering Failure Analysis. Vol. 2017, no. 79(2017), p. 845-851.

8. WOJNAR G., CZECH P., FOLEGA P.: Problem with diagnosing local faults of gearboxes on the bassic of vibration signal. In: Transactions of the Universities of Košice, č. 2. (2014), 95-100.

9. FENG W., FENG Z., MAO L.: Failure analysis of a secondary driving helical gear in transmission of electric vehicle. In: Engineering Failure Analysis, 117 (2020), 8-19.

10. MO S., GONG J., JIN G., ZHU S., ZHANG T., FENG Z., CAO X.: Precise modeling of complex tooth surface microtopography and multi-degree-of-freedom nonlinear friction dynamics for high-performance face gear. In: Science Progress, 2020, p. 103-113 
